Virdyra Tasril ${ }^{1),}$ Khairul $^{2)}$ Fachrina Wibowo ${ }^{3)}$ Informatika : Jurnal Ilmiah Fakultas Sains dan Teknologi,

\title{
APLIKASI SISTEM INFORMASI UNTUK MENENTUKAN KUALITAS BERAS BERBASIS ANDROID PADA KELOMPOK TANI JAYA MAKMUR DESA BENYUMAS
}

\author{
Virdyra Tasril $^{1)}$ Khairul $^{2)}$ Fachrina Wibowo $^{3)}$ \\ ${ }^{123}$ Universitas Pembangunan Pancabudi \\ virdyra@dosen.pancabudi.ac.id ${ }^{1)}$ khairul@dosen.pancabudi.ac.id $\left.{ }^{2}\right)$ \\ fachrinawibowo@dosen.pancabudi.ac.id ${ }^{3)}$
}

\begin{abstract}
Komoditas pangan merupakan salah satu komoditas penting dalam kehidupan manusia. Salah satu komoditas pangan yang menjadi bahan pangan dominan di hampir semua negara asia adalah beras, khususnya untuk negara-negara di kawasan Asia Tenggara. Karakter beras secara umum dipengaruhi oleh faktor genetik dan lingkungan. Faktor genetik padi merupakan faktor utama penentu karakter gabah dan beras. Penelitian ini memiliki tujuan dapat membantu dalam penilaian kualitas beras para petani dengan mudah. Dengan aplikasi sistem informasi berbasis android ini dapat memudahkan para kelompok tani dalam memberikan penilaian kualitas beras dan bisa digunakan dimana saja dengan menggunakan smartphone berbasis android.
\end{abstract}

Keywords: Android, Beras, Kelompok Tani

\section{PENDAHULUAN}

Ketergantungan penduduk Indonesia terhadap makanan pokok beras sangat tinggi. Sekalipun Negara Indonesia adalah Negara agraris, Indonesia masih mengimpor beras untuk memenuhi kebutuhan akan beras. Upaya mengurangi ketergantungan masyarakat Indonesia dalam mengkonsumsi beras yang sangat tinggi adalah dengan diversifikasi konsumsi pangan 2 alternatif. Program diversifikasi pangan belum dapat berhasil sepenuhnya karena keterikatan masyarakat yang sangat kuat dengan konsumsi beras (Rachman, 2008).

Pemilihan beras untuk dikonsumsi dalam pemenuhan asupan sehari-hari tergantung pada selera konsumen. Konsumen adalah pribadi seseorang yang mendorong keinginan untuk melakukan kegiatan-kegiatan guna mencapai suatu tujuan (Setiadi, 2003).
Pada tahun 2014 konsumsi beras di Indonesia sebesar 96,32 kg/ kapita/ tahun. Meskipun mengalami penurunan dari tahun sebelumnya, akan tetapi masih jauh melebihi rata-rata tingkat konsumsi beras dunia yaitu sebesar $60 \mathrm{~kg} / \mathrm{kapita} / \mathrm{tahun}$. Hal ini akibat dari kebijakan pemerintah mengenai pergeseran pangan pokok dari pangan lokal seperti jagung dan umbiumbian ke pangan pokok nasional yaitu beras. Dengan kondisi ketergantungan pangan pada satu jenis produk dapat menjadikan Indonesia rawan pangan, oleh sebab itu diperlukan pengembangan produk pangan pokok lain pengganti beras (Kementerian Riset dan Teknologi, 2014).

Komoditas pangan merupakan salah satu komoditas penting dalam kehidupan manusia. Peranan penting bahan pangan tersebut menjadi dasar untuk perkembangan dunia usaha yang berkaitan dengan komoditas pangan dan bahan olahan dari setiap bahan pangan yang ada. 
Virdyra Tasril ${ }^{1),}$ Khairul $^{2)}$ Fachrina Wibowo ${ }^{3)}$ Informatika : Jurnal Ilmiah Fakultas Sains dan Teknologi,

Salah satu komoditas pangan yang menjadi bahan pangan dominan di hampir semua negara asia adalah beras, khususnya untuk negara-negara di kawasan Asia Tenggara.

Karakter beras secara umum dipengaruhi oleh faktor genetik dan lingkungan. Faktor genetik padi merupakan faktor utama penentu karakter gabah dan beras. Ukuran dan bentuk, warna, pengapuran (chalky), kandungan amilosa-amilopektin, konsistensi gel, suhu gelatinisasi, dan aroma beras merupakan karakter yang diturunkan secara genetik. Faktor lingkungan yang mempengaruhi karakter varietas antara lain adalah butir kuning rusak, butir hijau mengapur, butir retak, dan kadar air beras.

Banyaknya faktor yang membuat kualitas beras berbeda-beda tersebut, dibutuhkannya penilaian pada kualitas beras yang dipanen. Melihat banyaknya kelompok tani dan jenis beras yang berbeda-beda tersebut, dibutuhkannya aplikasi yang dapat melakukan penilaian pada kelompok tani yang bercocok tanam tanaman padi agar dapat memberikan penilaian pada beras yang dihasilkannya. Aplikasi yang akan dibangun ini menggunakan metode weighted product dalam proses pemberian nilai pada masing-masing kelompok tani yang menghasilkan berasnya. Aplikasi juga dibuat dengan berbasis mobile sehingga dapat digunakan dimana saja dengan menggunakan smartphone bersistem operasi android.

\section{LANDASAN TEORI}

\subsection{Sistem}

Pengertian sistem menurut McLeod yang dikutip oleh Machmud (2013) adalah sebagai berikut : "A sistem is a group of elements that are integrated with the common porpose of achieving an objective". Sistem merupakan sekelompok elemen yang terintegrasi dengan maksud yang sama untuk mencapai suatu tujuan. (Machmud, 2013)

Menurut Andalia F and Setawan EB (2015), Sistem adalah suatu jaringan kerja dari prosedur-prosedur yang saling berhubungan, berkumpul bersama-sama untuk melakukan suatu kegiatan atau untuk menyelesaikan suatu sasaran tertentu.

\subsection{Informasi}

Menurut McFadden,dkk yang dikutip oleh (Abdul Kadir, 2003) "mendefinisikan informasi sebagai data yang telah diproses sedemikian rupa sehingga meningkatkan pengetahuan seseorang yang menggunakan data tersebut.Sedangkan menurut Davis informasi adalah data yang telah diolah menjadi sebuah bentuk yang berarti bagi penerimanya dan bermanfaat dalam pengambilan keputusan saat ini atau saat mendatang".

Informasi ibarat data yang mengalir di dalam tubuh suatu organisasi, sehingga informasi ini sangat penting di dalam suatu organisasi. Suatu sistem yang kurang mendapatkan informasi akan menjadi luruh,kerdil dan akhirnya berakhir. Jadi informasi itu sangat penting sekali artinya bagi suatu sistem sehingga suatu informasi adalah data yang diolah menjadi bentuk yang lebih berguna dan lebih berarti bagi yang menerimanya. (Jogiyanto HM, 2005)

Suatu informasi akan mempunyai suatu nilai dan manfaat apabila suatu informasi tersebut mempunyai kualitas, Kualitas dari suatu informasi tergantung dari tiga hal, yaitu informasi harus akurat (accurate), tepat pada waktunya (timelines) dan relevan (relevance). (Jogiyanto HM, 2005)

\subsection{Aplikasi Mobile}

Aplikasi Mobile adalah sebuah aplikasi yang memungkinkan Anda 
Virdyra Tasril ${ }^{1),}$ Khairul $^{2)}$ Fachrina Wibowo ${ }^{3)}$ Informatika : Jurnal Ilmiah Fakultas Sains dan Teknologi,

Universitas Labuhanbatu

Vol.7 No.3/September/2019

2615-1855 (E-ISSN)

2303-2863 (P-ISSN)

melakukan mobilitas dengan menggunakan perlengkapan seperti PDA, telepon seluler atau Handphone. Dengan menggunakan aplikasi Mobile, Anda dapat dengan mudah melakukan berbagai macam aktifitas mulai dari hiburan, berjualan, belajar, mengerjakan pekerjaan kantor, browsing dan lain sebagainya. Pemanfaatan aplikasi Mobile untuk hiburan paling banyak digemari oleh hampir $70 \%$ pengguna telepon seluler, karena dengan memanfaatkan adanya fitur game, music player, sampai video player membuat kita menjadi semakin mudah menikmati hiburan kapan saja dan dimanapun. (Kosidin, 2016)

\subsection{Android}

Android merupakan salah satu Mobile Operating System atau sistem operasi handphone yang berupa software platform open source untuk Mobile device, yang mana Mobile Operating System yaitu sistem operasi yang dapat mengontrol sistem dan kinerja barang elektronik berbasis Mobile, yang fungsinya sama seperti Windows, Linux dan Mac OS X pada desktop PC atau Notebook atau Laptop tetapi lebih sederhana. (Muharom, 2013)

Android merupakan sistem operasi yang berisi middleware serta aplikasiaplikasi dasar. Basis sistem operasi Android yaitu kernel linux 2.6 yang telah diperbaharui untuk Mobile device. Pengembangkan aplikasi Android menggunakan bahasa pemrograman java. Yang mana konsep-konsep pemrograman java berhubungan dengan Pemrograman Berbasis Objek (OOP)). Selain itu pula dalam pengembangan aplikasi Android membutuhkan software development kit (SDK) yang disediakan Android, SDK ini memberi jalan bagi programmer untuk mengakses application programming interface (API ) pada Android.

\subsection{Arsitektur Android}

Setiap lapisan dari tumpukan ini menghimpun beberapa program yang mendukung fungsi-fungsi spesifik dari sistem operasi. Pada lapisan application framework yang mencakup program untuk mengatur fungsi dasar smartphone. Application Framework merupakan serangkaian tool dasar seperti alokasi resource smartphone, aplikasi telepon, pergantian antar proses atau program, dan pelacakan lokasi fisik telepon. Para pengembang aplikasi memiliki aplikasi penuh kepada tool dasar tersebut, dan memanfaatkannya untuk menciptakan aplikasi yang lebih kompleks. Arsitektur aplikasi didesain untuk menyederhanakan pemakaian kembali komponen komponen, setiap aplikasi dapat menunjukkan kemampuannya dan aplikasi lain dapat memakai kemampuan tersebut. Mekanisme yang sama memungkinkan pengguna mengganti komponen komponen yang dikehendaki. (Fahnun, 2013)

\subsection{Beras}

Beras adalah gabah yang bagian kulitnya sudah dibuang dengan cara digiling dan disosoh menggunakan alat pengupas dan penggiling (huller) serta penyosoh (polisher). Beras merupakan komoditas yang penting karena merupakan kebutuhan pangan pokok yang setiap saat harus dapat dipenuhi. (Pontoh, 2016)

Beras merupakan makanan pokok pada hampir seluruh masyarakat di benua Asia. Beras menyumbang lebih dari 22\% dari asupan energi global. Asia adalah produsen beras utama, dimana jumlah produksi padi sekitar $92 \%$ dari total produksi dunia.1,2 Bagi bangsa-bangsa di Asia, beras merupakan pangan pokok yang cukup dominan. Walaupun bervariasi antar Negara, namun sumbangan beras terhadap pemenuhan kebutuhan kalori dalam diet 
Virdyra Tasril ${ }^{1),}$ Khairul $^{2)}$ Fachrina Wibowo ${ }^{3)}$ Informatika : Jurnal Ilmiah Fakultas Sains dan Teknologi,

sehari-hari masyarakat Asia masih relatif cukup tinggi. (Nuryani, 2013)

\subsection{Android Studio}

Android studio adalah IDE (Integrated Development Environment) resmi untuk pengembangan aplikasi Android dan bersifat open source atau gratis. Peluncuran Android Studio ini diumumkan oleh Google pada 16 mei 2013 pada event Google I/O Conference untuk tahun 2013. Sejak saat itu, Android Studio mengantikan Eclipse sebagai IDE resmi untuk mengembangkan aplikasi Android (Andi Juansyah, 2015).

\subsection{Java Development Kit (JDK)}

Java Development Kit (JDK) adalah sekumpulan perangkat lunak yang dapat kamu gunakan untuk mengembangkan perangkat lunak yang berbasis Java, sedangkan JRE adalah sebuah implementasi dari Java Virtual Machine yang benar-benar digunakan untuk menjalankan program java. Biasanya, setiap JDK berisi satu atau lebih JRE dan berbagai alat pengembangan lain seperti sumber compiler java, bundling, debuggers, development libraries dan lain sebagainya (Andi Juansyah, 2015).

\subsection{Alat Bantu Perancangan Sistem 2.9.1 Data Flow Diagram}

Digram Konteks adalah diagram yang terdiri dari suatu proses dan menggambarkan ruang lingkup suatu sistem, dan di dalam diagram konteks hanya ada satu proses serta tidak boleh ada store di dalamnya (Ladjamudin, 2013).

Diagram konteks merupakan alat dalam perancangan secara global atau umum bagi perancangan sebuah sistem yang akan di buat, yang bertujuan untuk mencerminkan keadaan sistem yang akan di bangun (Abdullah, 2014).
Tabel 1. Simbol DFD

\begin{tabular}{|c|c|l|}
\hline Simbol & Nama & \multicolumn{1}{|c|}{ Keterangan } \\
\hline Entitas & $\begin{array}{l}\text { Sesuatu yang berada diluar } \\
\text { sistem, tetapi ia memberikan } \\
\text { data ke dalam sistem atau dari } \\
\text { sistem }\end{array}$ \\
\hline Proses & $\begin{array}{l}\text { Mentransformasikan satu atau } \\
\text { beberapa data masukan menjadi } \\
\text { satu atau beberapa data keluaran } \\
\text { sesuai dengan spesifikasi yang } \\
\text { dinginkan }\end{array}$ \\
\hline Arus Data & $\begin{array}{l}\text { Tempat mengalirnya informasi } \\
\text { yang menghubungkankomponen } \\
\text { dari sistem }\end{array}$ \\
\hline & Data Store & $\begin{array}{l}\text { Tempat penyimapanan data dan } \\
\text { pengikat data yang ada dalam } \\
\text { sistem }\end{array}$ \\
\hline
\end{tabular}

Ladjamudin, 2013

\section{METODE PENELITIAN}

Di sini diuraikan metodologi dan kerangka kerja penelitian digunakan untuk mengambarkan langkah-langkah yang akan diterapkan dalam melakukan penelitian.

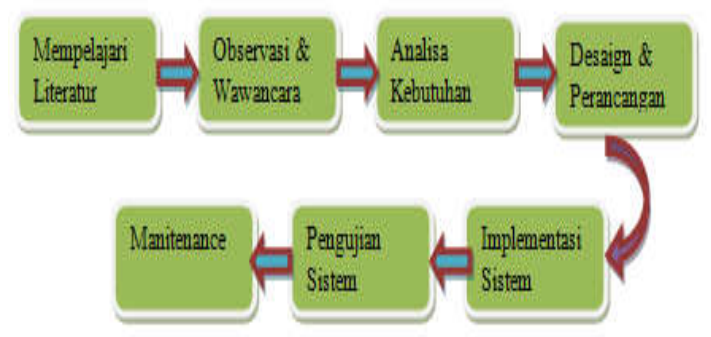

Gambar 1. Metode Penelitian

1) Mempelajari Literatur

Pada penelitian ini dipelajari literatur yang berhubungan dengan permasalahan. Kemudian literatur yang dipelajari diseleksi untuk dapat ditentukan literatur mana yang akan digunakan dalam penelitian. Sumber literatur didapatkan dari perpustakaan, jurnal, artikel dan konsep-konsep lain yang mendukung dalam menyelesaikan sistem yang akan dibangun termasuk referensi.

2) Pengumpulan Data

Dalam melakukan penelitian ini, pengumpulan data dan informasi pada 
Virdyra Tasril ${ }^{1),}$ Khairul $^{2)}$ Fachrina Wibowo ${ }^{3)}$ Informatika : Jurnal Ilmiah Fakultas Sains dan Teknologi,

Universitas Labuhanbatu

Vol.7 No.3/September/2019

2615-1855 (E-ISSN)

2303-2863 (P-ISSN)

tahap ini dilakukan untuk mengetahui mengenai sistem yang diteliti.

3) Analisa Kebutuhan

Analisis dapat didefinisikan sebagai penguraian dari suatu sistem informasi yang utuh kedalam bagian-bagian komponennya. Analisa kebutuhan ini bertujuan untuk mengetahui apa saja yang dibutuhkan dalam perancangan sistem yang di bangun dan mengetahui kebutuhan-kebutuhan pendukung dari perancangan sistem.

4) Desain dan Perancangan Sistem

Kegiatan desain sistem dilakukan untuk sebagai awal dari perancangan sistem yang akan dibangun sesuai kebutuhan.

5) Implementasi Sistem

Implementasi sistem dilakukan sesuai desain dan rancangan antar muka aplikasi yang akan dibangun. Pada tahap ini melakukan pengkodingan atau pembuatan program sehingga sistem yang dirancang dapat digunakan oleh pengguna.

6) Pengujian Sistem

Pengujian sistem dilakukan untuk mengetahui uji kelayakan sistem yang telah dibangun sesuai yang diharapkan dan dengan dilakukannya pengujian dapat mengetahui kelemahan serta kelebihan dari sistem yang dirancang sehingga dapat dilakukan perbaikan pada tahap selanjutnya.

7) Maintenance

Pemeliharaan Sistem.

\subsubsection{Flowchart}

Diagram alir atau Flowchart merupakan serangkaian bagan-bagan yang menggambarkan alir program. Pada diagram alir ini digambarkan urutan prosedur dalam sistem aplikasi. (Dara, 2014)

Flowchart atau bagan alur merupakan metode untuk menggambarkan tahap-tahap penyelesaian masalah (prosedur) beserta aliran data dengan simbolsimbol standar yang mudah di pahami. Tujuan utama penggunaan flowchart adalah untuk menyederhanakan rangkaian proses atau prosedur untuk memudahkan pemahaman pengguna terhadap informasi tersebut. (Wongso, 2015)

Tabel 2. Simbol Flowchart

\begin{tabular}{|c|c|c|}
\hline No & Simbol & Fungsi \\
\hline 1 & & $\begin{array}{lr}\text { Terminal } & \text { untuk } \\
\text { memulai } & \text { dan } \\
\text { mengakhiri } & \text { suatu } \\
\text { program. } & \end{array}$ \\
\hline 2 & & $\begin{array}{lr}\text { Proses, } & \text { suatu } \\
\text { simbol } & \text { yang } \\
\text { menunjukkan } & \text { sikap } \\
\text { pengolahan } & \text { yang } \\
\text { dilakukan } & \text { oleh } \\
\text { komputer. } & \end{array}$ \\
\hline 3 & & $\begin{array}{l}\text { Input-Output, } \\
\text { untuk memasukkan } \\
\text { data maupun } \\
\text { menunjukkan hasil } \\
\text { dari suatu proses. }\end{array}$ \\
\hline 4 & & $\begin{array}{l}\text { PreddifinedProcess, } \\
\text { suatu simbol untuk } \\
\text { menyedidakan } \\
\text { tempat-tempat } \\
\text { pengolahan data } \\
\text { dalam storage. }\end{array}$ \\
\hline 5 & & $\begin{array}{ll}\text { Decision, suatu } \\
\text { kondisi yang } \\
\text { menghasilkan } \\
\text { beberapa } \\
\text { kemungkinan } \\
\text { jawaban } \quad \text { atau }\end{array}$ \\
\hline
\end{tabular}




\begin{tabular}{|c|c|}
\hline & pilihan. \\
\hline 6 & $\begin{array}{l}\text { Connector, suatu } \\
\text { prosedur akan } \\
\text { masuk dan keluar } \\
\text { melalui simbol ini } \\
\text { dalam lembar yang } \\
\text { sama. }\end{array}$ \\
\hline 7 & $\begin{array}{l}\text { Off line connector, } \\
\text { merupakan simbol } \\
\text { untuk masuk dan } \\
\text { keluarnya suatu } \\
\text { prosedur pada } \\
\text { lembar kertas yang } \\
\text { lain. }\end{array}$ \\
\hline 8 & $\begin{array}{l}\text { Arus atau flow, } \\
\text { prosedur yang } \\
\text { dapat dilakukan } \\
\text { dari atas kebawah, } \\
\text { bawah keatas, dari } \\
\text { kekanan, atau dari } \\
\text { kanan kekiri. }\end{array}$ \\
\hline 9 & $\begin{array}{l}\text { Document, } \\
\text { merupakan simbol } \\
\text { untuk data yang } \\
\text { berbentuk } \\
\text { informasi. }\end{array}$ \\
\hline 10 & $\begin{array}{l}\text { Untuk menyatakan } \\
\text { sekumpulan } \\
\text { langkah proses } \\
\text { yang ditulis sebagai }\end{array}$ \\
\hline
\end{tabular}

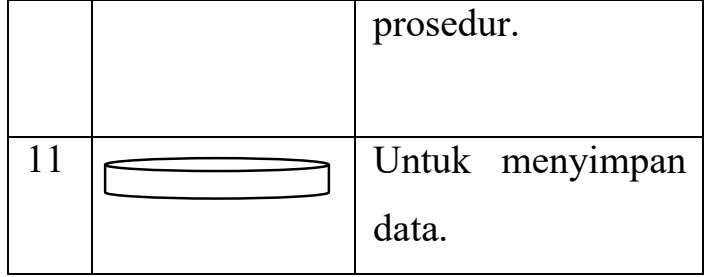

Ladjamudin, 2013

\section{II.METODE PENELITIAN}

Di sini diuraikan metodologi dan kerangka kerja penelitian digunakan untuk mengambarkan langkah-langkah yang akan diterapkan dalam melakukan penelitian.

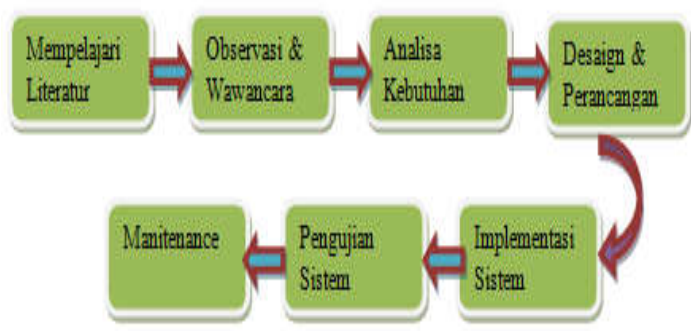

Gambar 1. Metode Penelitian

1. Mempelajari Literatur

Pada penelitian ini dipelajari literatur yang berhubungan dengan permasalahan. Kemudian literatur yang dipelajari diseleksi untuk dapat ditentukan literatur mana yang akan digunakan dalam penelitian. Sumber literatur didapatkan dari perpustakaan, jurnal, artikel dan konsep-konsep lain yang mendukung dalam menyelesaikan sistem yang akan dibangun termasuk referensi.

2. Pengumpulan Data

Dalam melakukan penelitian ini, pengumpulan data dan informasi pada tahap ini dilakukan untuk mengetahui mengenai sistem yang diteliti.

3. Analisa Kebutuhan

Analisis dapat didefinisikan sebagai penguraian dari suatu sistem informasi yang utuh kedalam bagian-bagian komponennya. Analisa kebutuhan ini bertujuan untuk mengetahui apa saja yang dibutuhkan dalam perancangan sistem yang di bangun dan mengetahui kebutuhan-kebutuhan pendukung dari perancangan sistem. 
4. Desain dan Perancangan Sistem Kegiatan desain sistem dilakukan untuk sebagai awal dari perancangan sistem yang akan dibangun sesuai kebutuhan.

5. Implementasi Sistem Implementasi sistem dilakukan sesuai desain dan rancangan antar muka aplikasi yang akan dibangun. Pada tahap ini melakukan pengkodingan atau pembuatan program sehingga sistem yang dirancang dapat digunakan oleh pengguna.

6. Pengujian Sistem

Pengujian sistem dilakukan untuk mengetahui uji kelayakan sistem yang telah dibangun sesuai yang diharapkan dan dengan dilakukannya pengujian dapat mengetahui kelemahan serta kelebihan dari sistem yang dirancang sehingga dapat dilakukan perbaikan pada tahap selanjutnya.

7. Maintenance

Pemeliharaan Sistem.

\section{IV.HASIL DAN PEMBAHASAN}

Komoditas pangan merupakan salah satu komoditas penting dalam kehidupan manusia. Peranan penting bahan pangan tersebut menjadi dasar untuk perkembangan dunia usaha yang berkaitan dengan komoditas pangan dan bahan olahan dari setiap bahan pangan yang ada. Salah satu komoditas pangan yang menjadi bahan pangan dominan di hampir semua negara asia adalah beras, khususnya untuk negara-negara di kawasan Asia Tenggara.

Karakter beras secara umum dipengaruhi oleh faktor genetik dan lingkungan. Faktor genetik padi merupakan faktor utama penentu karakter gabah dan beras. Ukuran dan bentuk, warna, pengapuran (chalky), kandungan amilosa-amilopektin, konsistensi gel, suhu gelatinisasi, dan aroma beras merupakan karakter yang diturunkan secara genetik. Faktor lingkungan yang mempengaruhi karakter varietas antara lain adalah butir kuning rusak, butir hijau mengapur, butir retak, dan kadar air beras.

\subsection{Analisa Sistem}

Hasil implementasi dalam membangun sistem pendukung keputusan untuk memilih kualitas beras terbaik. Tahap ini akan menjelaskan apakah setiap proses dapat berjalan dengan baik dan mampu memberikan hasil yang diharapkan dan memudahkan dalam menentukan kualitas beras terbaik.

\subsection{Desaign Sistem Secara Global}

Perancangan aplikasi kebudayaan ini dirancang menggunakan alat bantu berupa Flowchart, Data Flow Diagram dan ERD agar mempermudah memindahkan konsep yang dirancang ke dalam bentuk program. Perancangannya digambarkan dalam bentuk diagram-diagram berikut :

\section{1) Flowchart}

Diagram Use-case menjelaskan manfaat sistem jika dilihat menurut aktor di luar sistem. Maksud aktor di sini bisa berupa orang maupun sistem lain yang terpisah dari sistem yang sedang dibuat. Diagram ini menunjukkan fungsionalitas suatu sistem atau kelas dan bagaimana sistem berinteraksi dengan dunia luar. 
Virdyra Tasril ${ }^{1),}$ Khairul $^{2)}$ Fachrina Wibowo ${ }^{3)}$ Informatika : Jurnal Ilmiah Fakultas Sains dan Teknologi,

Universitas Labuhanbatu

Vol.7 No.3/September/2019

2615-1855 (E-ISSN)

2303-2863 (P-ISSN)

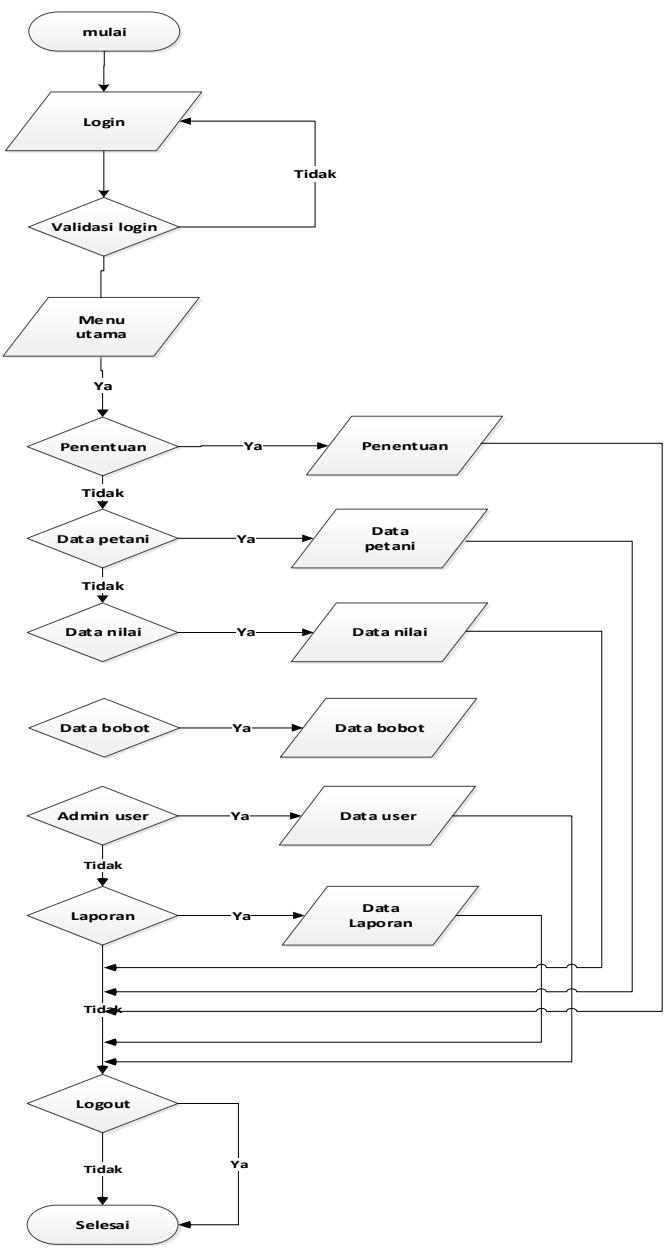

Gambar 1. Flowchart Sistem

2) Konteks Diagram

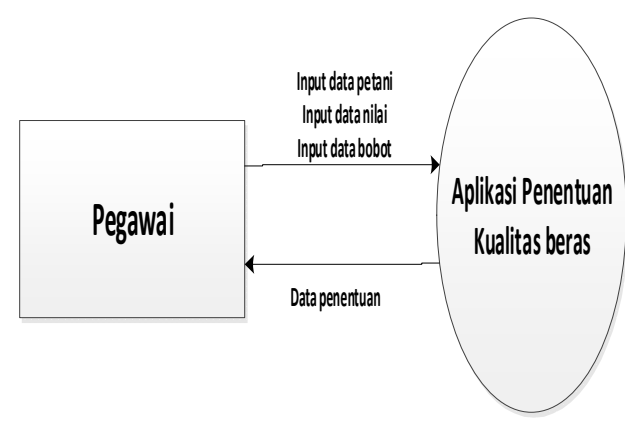

Gambar 2. Konteks Diagram
3) Data Flow Diagram Level 0

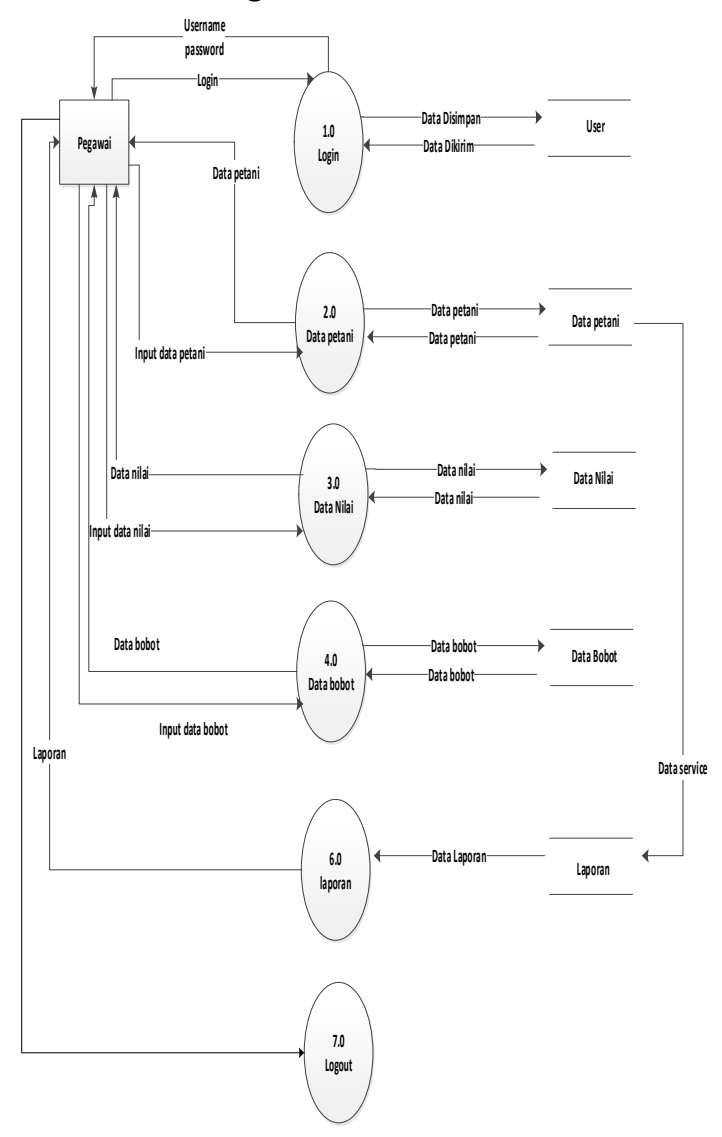

Gambar 3. DFD Level 0

\subsection{Implementasi}

Pengujian aplikasi dilakukan agar aplikasi dapat dioperasikan oleh pengguna atau user dan mengetahui bagaimana cara menentukan kualitas beras terbaik dengan menggunakan aplikasi yang ada.

1) Tampilan Utama

Merupakan hasil tampilan dari halaman utama. Tampilan ini merupakan tampilan dari aplikasi disaat pertama kali dibuka. Pada tampilan ini, pengguna dapat memilih tiga menu yang telah disediakan diantaranya yaitu Tambah Data, Analisa Data dan Data Beras. 
Virdyra Tasril ${ }^{1),}$ Khairul $^{2)}$ Fachrina Wibowo ${ }^{3)}$ Informatika : Jurnal Ilmiah Fakultas Sains dan Teknologi,

Universitas Labuhanbatu

Vol.7 No.3/September/2019

2615-1855 (E-ISSN)

2303-2863 (P-ISSN)

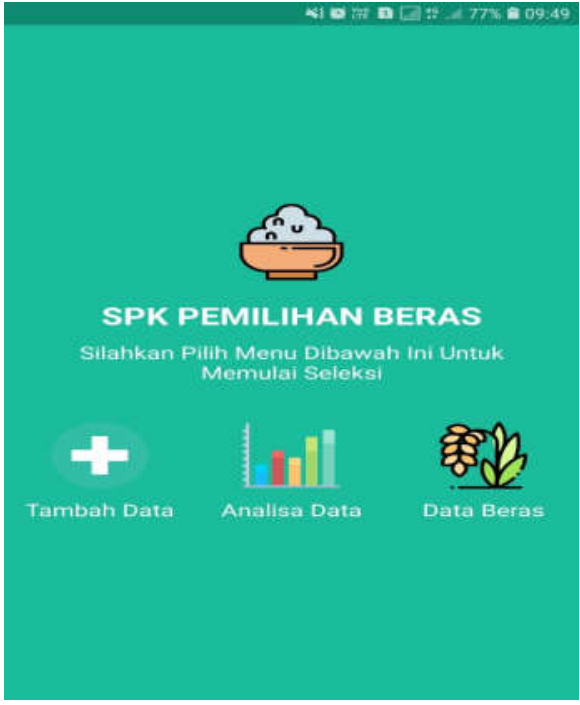

Gambar 4. Tampilan Utama

2)Tampilan tambah Data Beras

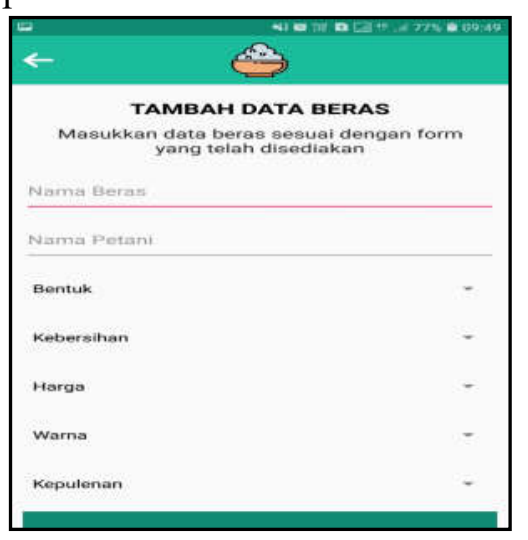

Gambar 5. Tambah Data Beras

2) Tampilan List Data Beras

Merupakan hasil tampilan dari list data beras. Pada tampilan ini, pengguna dapat melihat list-list beras yang telah berhasil diunggah ke aplikasi. Pada tampilan ini juga pengguna dapat menghapus dan mengubah data beras dengan menekan tombol yang telah disediakan.

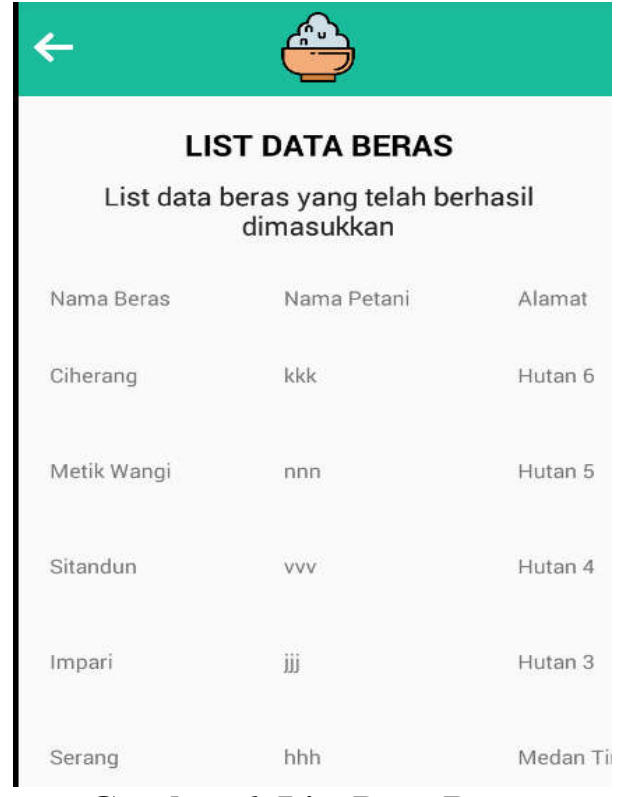

Gambar 6. List Data Beras

3) Tampilan Analisa Data

Merupakan hasil tampilan dari analisa data. Pada tampilan ini, pengguna dapat melihat proses perhitungan dari metode weighted product berdasarkan dari data-data beras yang telah dimasukkan.

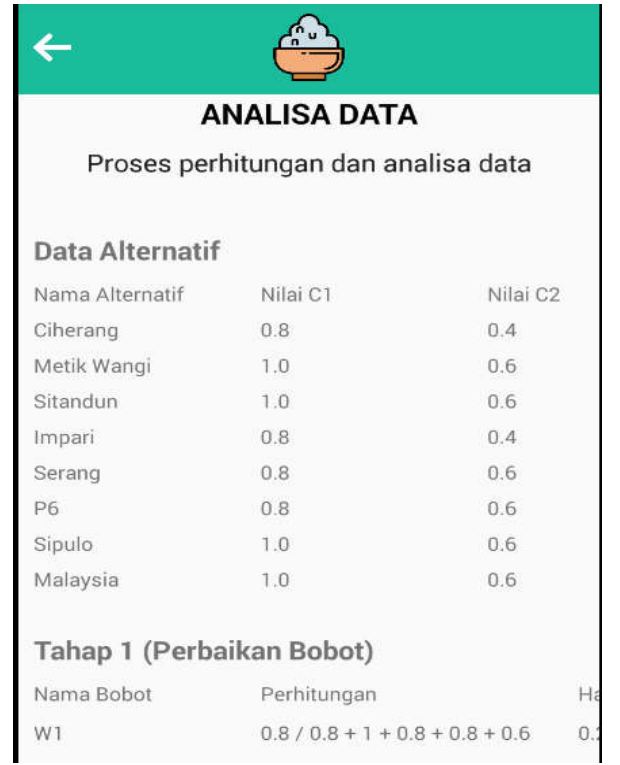

Gambar 7. Analisa Data 
Virdyra Tasril ${ }^{1),}$ Khairul $^{2)}$ Fachrina Wibowo ${ }^{3)}$ Informatika : Jurnal Ilmiah Fakultas Sains dan Teknologi,

Universitas Labuhanbatu

Vol.7 No.3/September/2019

2615-1855 (E-ISSN)

2303-2863 (P-ISSN)

4) Hasil Perhitungan dan Perengkingan Merupakan hasil dari tampilan perankingan data beras menggunakan metode weighted product. Pada tampilan ini, pengguna dapat melihat beras mana yang menempati ranking pertama dan beras mana yang menempati ranking terakhir

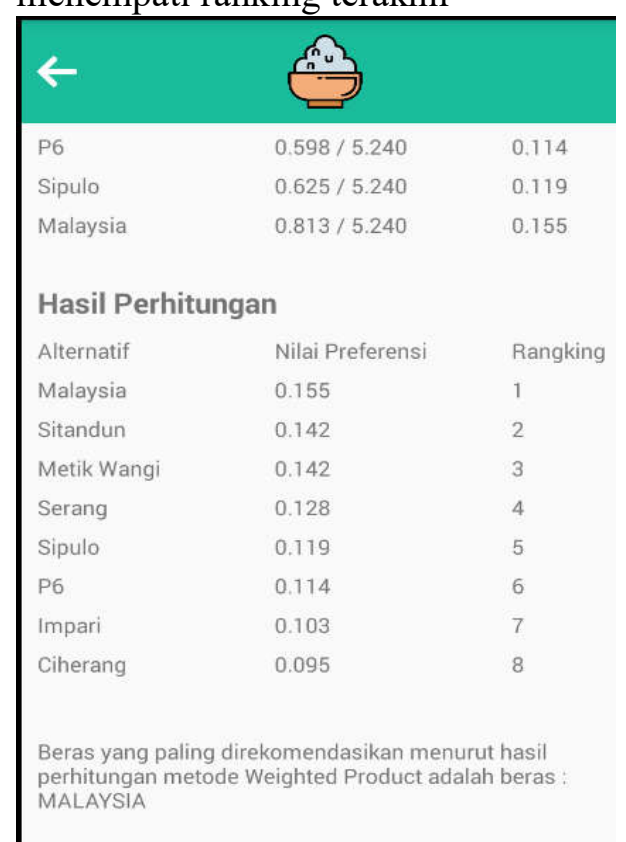

Gambar 8. Hasil Perhitungan dan Perengkingan

\section{IV.KESIMPULAN}

Berdasarkan hasil penelitian yang telah dilakukan dapat diambil kesimpulan sebagai berikut:

1. Hasil dari pembuatan sistem ini dapat digunakan secara cepat dan mudah baik bagi orang biasa ataupun petani beras karena mereka cukup memilih kriteria-kriteria yang telah disediakan oleh aplikasi.

2. Proses perankingan juga dilakukan secara terbuka mulai dari pengambilan data sampai pada perhitungan preferensi. Dengan ini, siapapun dapat melihat beras yang berkualitas paling baik sampai pada beras yang berkualitas paling
burukSMA berbasis macromedia flash ini, dapat meningkatkan minat belajar siswa.

7. REFERENSI

[1] Andalia $\mathrm{H}$ and Setiawan EB, 2015. Pengembangan Sistem Informasi Pengolahan Data Pencari Kerja Pada Dinas Sosial Dan Tenaga Kerja Kota Padang. Padang.

[2] Machmud, R. (2013). Peranan Penerapan Sistem Informasi Manajemen Terhadap Efektivitas Kerja Pagawai Lembaga Pemasyarakatan Narkotika (Lapastika) Bollangi Kabupaten Gowa. Jurnal Capacity STIE AMKOP Makassar, 9(3), 409-421

[3] Minarni Dkk. (2011). Sistem Informasi Perpustakaan Berbasis Web Pada Politeknik Kesehatan Padang. Jurnal Teknologi Informasi \& Pendidikan ITP, 3(1), 102-109. 